Article

\title{
Effect of Heat Treatment on the Microstructure and Phase Composition of $\mathrm{ZrB}_{2}-\mathrm{MoSi}_{2}$ Coating
}

\author{
Marina Kovaleva ${ }^{1, * \mathbb{D}}$, Igor Goncharov ${ }^{1,2}$, Vseslav Novikov ${ }^{1}$, Maxim Yapryntsev ${ }^{1}$, \\ Olga Vagina ${ }^{1}$, Ivan Pavlenko ${ }^{1}$, Viacheslav Sirota ${ }^{2}$, Yuri Tyurin ${ }^{3}$ and Oleg Kolisnichenko ${ }^{3} \mathbb{D}$ \\ 1 Belgorod State National Research University, Pobeda 85, 308015 Belgorod, Russia; \\ goncharov@bsu.edu.ru (I.G.); novikov_v@bsu.edu.ru (V.N.); yaprintsev@bsu.edu.ru (M.Y.); \\ vagina@bsu.edu.ru (O.V.); dancer.disco@mail.ru (I.P.) \\ 2 Belgorod State Technological University named after V.G. Shoukhov, Kostyukov 46, 308012 Belgorod, Russia; \\ zmas36@mail.ru \\ 3 E.O. Paton Electric Welding Institute, NASU, Bozhenko 11, 03650 Kyiv, Ukraine; y.n.tyurin@rambler.ru (Y.T.); \\ okolis@i.ua (O.K.) \\ * Correspondence: kovaleva@bsu.edu.ru; Tel.: +7-4722-585-415
}

Received: 9 October 2019; Accepted: 20 November 2019; Published: 21 November 2019

\begin{abstract}
Composite $\mathrm{ZrB}_{2}-\mathrm{MoSi}_{2}$ coating modified by $\mathrm{Y}_{2} \mathrm{O}_{3}$ and $\mathrm{Al}$ was prepared by a new multi-chamber detonation accelerator (MCDS) on carbon/carbon composites. Postdeposition heat treatment of the samples at $1500^{\circ} \mathrm{C}$ for 1 and $6 \mathrm{~h}$ was carried out in air. The effect of heat treatment on the microstructure and phase composition of the $\mathrm{ZrB}_{2}-\mathrm{MoSi}_{2}$ coating was investigated by scanning electron microscopy and $\mathrm{X}$-ray diffraction phase analysis. The as-sprayed coating presented as a dense lamellar structure, composed of $\mathrm{m}-\mathrm{ZrO}_{2}, \mathrm{t}-\mathrm{ZrO}_{2}$, some hexagonal $\mathrm{ZrB}_{2}$, and cubic $\mathrm{Al}$ phases. The $\mathrm{m}-\mathrm{ZrO}_{2}, \mathrm{c}-\mathrm{ZrO}{ }_{2}$, and $\mathrm{h}-\left(\alpha-\mathrm{Al}_{2} \mathrm{O}_{3}\right)$ formed at $1500{ }^{\circ} \mathrm{C}$. The coatings after heat treatment ( 1 and $6 \mathrm{~h}$ ) exhibited a structure without cracks. The porosity $(\sim 1 \%)$ of the coating did not change after heat treatment. Thin, continuous, silica-rich film covered the surfaces of $\mathrm{ZrO}_{2}$ and $\mathrm{Al}_{2} \mathrm{O}_{3}$ particles, and could have played a role during heat treatment by acting as a grain lubricant for particle rearrangement.
\end{abstract}

Keywords: carbon/carbon composites; $\mathrm{ZrB}_{2}-\mathrm{MoSi}_{2}$; multi-chamber detonation accelerator; thermal treatment; microstructure; $X$-ray methods

\section{Introduction}

Carbon/carbon $(\mathrm{C} / \mathrm{C})$ composites have attracted attentions in recent decades, owing to their low density $\left(<2.0 \mathrm{~g} / \mathrm{cm}^{3}\right)$, high strength and modulus, low coefficient of thermal expansion, good thermal impact resistance, and stable mechanical properties at elevated temperatures, which makes them a logical choice as thermal structural materials in the field of aeronautics and astronautics $[1,2]$. The properties of $\mathrm{C} / \mathrm{C}$ composites change in air with prolonged exposure to relatively low temperatures. $\mathrm{C} / \mathrm{C}$ composites are easily oxidized above $400{ }^{\circ} \mathrm{C}$ in oxygen-containing environments, which limits their high-temperature applications [3-5].

Coating is a feasible method to protect them against oxidation [3,6,7]. $\mathrm{ZrB}_{2}-\mathrm{MoSi}_{2}$ has been a common high-temperature, oxidation-resistant coating system in recent years [8-10]. $\mathrm{ZrB}_{2}$ and $\mathrm{MoSi}_{2}$ are considered ideal coating materials in thermal protective systems, because of their excellent high-temperature mechanical properties and good thermal shock and oxidation resistance [7-10]. The preparation methods of $\mathrm{ZrB}_{2}-\mathrm{MoSi}_{2}$ coatings include pack cementation, the slurry method, chemical vapor deposition, atmospheric plasma spraying, and thermal spray [11-14]. All of these methods require special preliminary surface preparation or the formation of a bonding sublayer 
between the coating material and substrate [10,15-17]. Thermal spraying is a highly efficient method to deposit coating. The use of high-speed gas-thermal methods, which impart high kinetic energy to powder particles while reducing their temperature, is expedient for obtaining coatings on the carbon-carbon materials surface. However, the sprayed coatings exhibit a porous structure [18], which cannot create an effective barrier from the corrosive environment for substrates.

In this study a new multi-chamber detonation accelerator (MCDS) was used to fabricate $\mathrm{ZrB}_{2}-\mathrm{MoSi}_{2}$ composite coating modified by $\mathrm{Y}_{2} \mathrm{O}_{3}$ and $\mathrm{Al}$ for the protection of carbon/carbon composites. The MCDS was equipped with a standard powder feeder (by Metco). The difference between MCDS and high-speed gas-thermal methods is that it sums up the energies of combustion products of fuel gas mixtures from several specially profiled detonation chambers. The accumulation of detonation energy from the two chambers in the cylindrical nozzle provides high-speed jet forming combustion products that effectively heat and accelerate the powder material. With MCDS technology, the energy of the fuel gas mixture was transformed into a high-velocity jet with a low thermal power, which allows the formation of a high-quality layer with no overheating of a workpiece. The use of MCDS makes it possible to form high-speed pulsed jets of heated ceramic powders $(2100 \pm 100 \mathrm{~m} / \mathrm{s})$, which provide the ability to create high contact loads upon the impact of discrete particles on the substrate surface, making it possible to deform ductile and destroy fragile substrate materials [19-21].

In the present work, the microstructural evolution of $\mathrm{ZrB}_{2}-\mathrm{MoSi}_{2}$ coatings during heat treatment at $1500{ }^{\circ} \mathrm{C}$ for 1 and $6 \mathrm{~h}$ in air was investigated. The main aim was to evaluate the microstructural stability of the $\mathrm{ZrB}_{2}-\mathrm{MoSi}_{2}$ coatings under high temperatures.

\section{Materials and Methods}

Composite powder $(\mathrm{d}(0.1): 1.69 \mu \mathrm{m}, \mathrm{d}(0.5): 10.03 \mu \mathrm{m}, \mathrm{d}(0.9): 23.86 \mu \mathrm{m})$ (Figure 1) containing $40.5 \mathrm{~mol} \%$ of $\mathrm{ZrB}_{2}, 5.3 \mathrm{~mol} \%$ of $\mathrm{MoSi}_{2}, 1.4 \mathrm{~mol} \%$ of $\mathrm{Y}_{2} \mathrm{O}_{3}$ and $52.8 \mathrm{~mol} . \%$ of $\mathrm{Al}$ was used as the feedstock material to deposit a dense layer on the carbon/carbon composites. Flat samples with a dimension of $15 \mathrm{~mm} \times 15 \mathrm{~mm} \times 5 \mathrm{~mm}$ were cut from bulk 3D C/C composites (NIIgraphit, Moscow, Russia) with a density of $1.9 \mathrm{~g} / \mathrm{cm}^{3}$. Those samples used as substrates were cleaned in an ultrasonic bath with ethanol and then dried at $80^{\circ} \mathrm{C}$ for $2 \mathrm{~h}$. In the present study, a multi-chamber detonation accelerator [19-21] was employed to deposit the $\mathrm{ZrB}_{2}-\mathrm{MoSi}_{2}$ coating. The parameters of the coating spray are listed in Table 1.

$\mathrm{Y}_{2} \mathrm{O}_{3}$ acts as a stabilizer of high-temperature tetragonal and cubic modification of zirconia [10]. Aluminum acts as a bonding material for the oxidizing agent in the process of spraying and to create "plastic" lamellae and nano-dispersed inclusions, in order to relieve internal stresses [22-24].
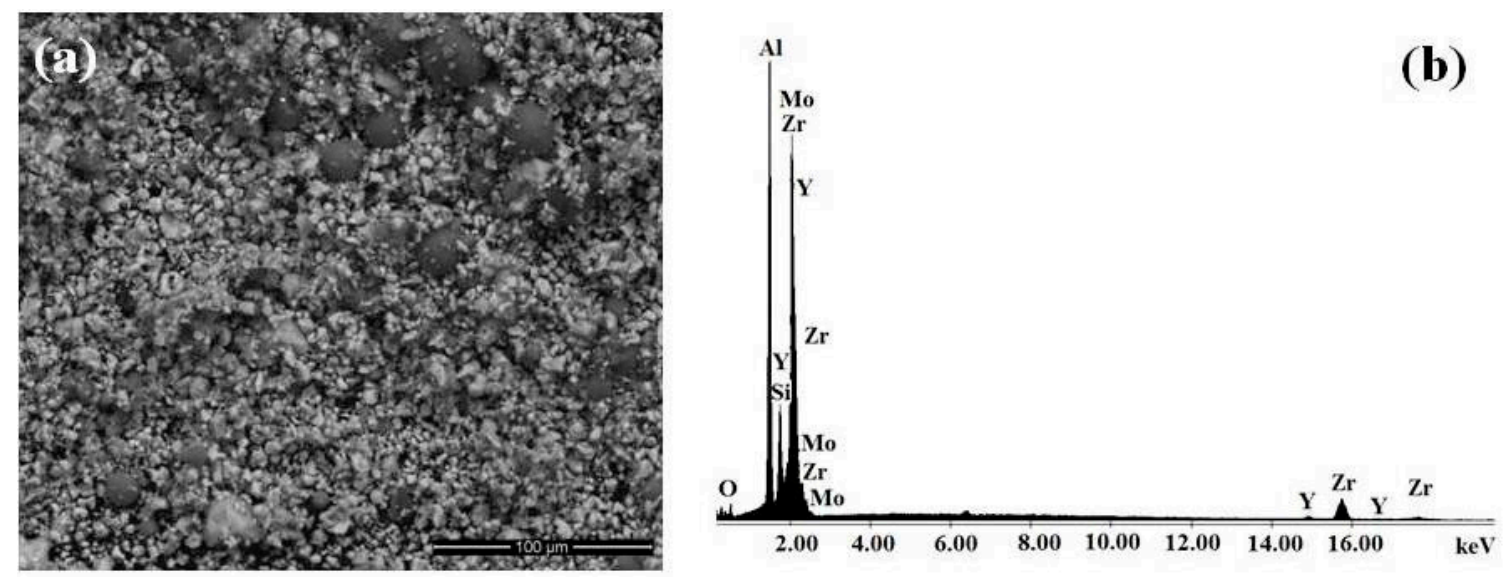

Figure 1. Scanning electron microscope using backscattered electrons (SEM-BSE) micrograph of the as received composite powder (a) and elemental chemical composition determined by energy-dispersive X-ray (EDX) spectroscopy (b). 
Table 1. Spraying parameters of coating.

\begin{tabular}{|c|c|c|c|c|c|c|c|}
\hline \multirow{2}{*}{9} & \multirow{2}{*}{$\begin{array}{c}\text { Barrel Length, } \\
\text { mm }\end{array}$} & \multirow{2}{*}{$\begin{array}{c}\text { Barrel } \\
\text { Diameter, mm }\end{array}$} & \multirow{2}{*}{$\begin{array}{l}\text { Powder Feed } \\
\text { Rate, g/h }\end{array}$} & \multicolumn{3}{|c|}{ Flow Rate of Fuel Mixture Components, $\mathrm{m}^{3} / \mathrm{h}$} & \multirow{2}{*}{$\begin{array}{c}\text { Oxygen/Fuel } \\
\text { Ratio }\end{array}$} \\
\hline & & & & Oxygen & $\mathrm{C}_{3} \mathrm{H}_{8}+\mathrm{C}_{4} \mathrm{H}_{10}$ & Air & \\
\hline 60 & 500 & 16 & 600 & $* 4.00 / * 3.60$ & $* 0.75 / * * 0.68$ & $* 0.12 / * * 0.12$ & 5.3 \\
\hline
\end{tabular}

The powder and fracture surfaces of the samples were investigated using a scanning electron microscope (SEM) (Quanta 600 FEG, FEI Company, Eindhoven, Netherlands) equipped with an EDAX Pegasus 2000 Energy Dispersive X-ray (EDX) (Mahwah, NJ, USA). Porosity was determined by metallographic method with elements of the qualitative and quantitative analyses of the geometry of the pores using an optical inverted Olympus GX51 microscope (Olympus Corporation, Tokyo, Japan). The phase composition of the powder and coatings was determined by the X-ray diffraction phase analysis method (diffractometer Rigaku Ultima IV, Tokyo, Japan. Crystalline phases were identified by the ICDD PDF-2 powder diffraction database release 2008.

The specimens were transversally cut, mechanically polished, and prepared by standard metallographic sample preparation methods of sectioning, mounting, and polishing. The sample was prepared by grinding with abrasive SiC paper (200, 500, 800, and 1000 grade), followed by polishing with $1-\mu \mathrm{m}$ diamond slurry according to the procedure recommended by Struers company for ceramic coatings.

A high-temperature furnace (LHT 04/17, Nabertherm $\mathrm{GmbH}$, Lilienthal, Germany) was used for the heat treatment of coatings in air. The samples were placed in the furnace and the furnace was heated at $5{ }^{\circ} \mathrm{C} / \mathrm{min}$ from 23 to $1500{ }^{\circ} \mathrm{C}$. The coatings were slowly cooled from 1500 to $50^{\circ} \mathrm{C}$ at a rate of $5^{\circ} \mathrm{C} / \mathrm{min}$ for $5 \mathrm{~h}$ in the furnace, and then allowed to cool to room temperature outside the furnace.

\section{Results}

Composite $\mathrm{ZrB}_{2}-\mathrm{MoSi}_{2}$ coatings with a thickness of 130-150 $\mu \mathrm{m}$ were deposited on the substrate. The XRD pattern of the as-received powder is given in Figure 2. It can be seen that the powder was composed of tetragonal $\mathrm{MoSi}_{2}$, hexagonal $\mathrm{ZrB}_{2}$, cubic $\mathrm{Y}_{2} \mathrm{O}_{3}$, and cubic Al phases (Figure 2a). After the deposition process, the monoclinic zirconia $\left(\mathrm{m}-\mathrm{ZrO}_{2}\right)$, some hexagonal $\mathrm{ZrB}{ }_{2}$, and cubic $\mathrm{Al}$ were identified in the coating. The $\mathrm{Y}_{2} \mathrm{O}_{3}$ stabilized tetragonal phase $\left(\mathrm{t}-\mathrm{ZrO}_{2}\right)$ was also found in the coating (Figure 2b). The spraying process was carried out in air, and the powder materials reacted with the oxygen to form new phases. $\mathrm{ZrO}_{2}$ is a reaction product of $\mathrm{ZrB}_{2}$ particles with oxygen during the deposition process $[25,26] . \mathrm{MoO}_{3}$ and $\mathrm{B}_{2} \mathrm{O}_{3}$ could hardly be detected in the XRD.

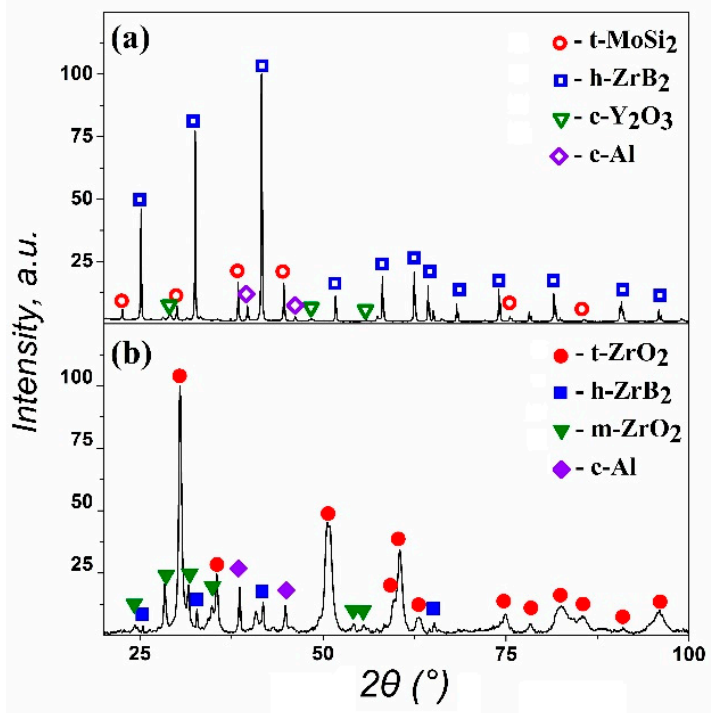

Figure 2. $\mathrm{XRD}$ diffractograms for as-received powder (a) and as-sprayed $\mathrm{ZrB}_{2}-\mathrm{MoSi}_{2}$ coating (b). 
XRD diffractograms for the coating after thermal treatment at $1500{ }^{\circ} \mathrm{C}$ in air are presented in Figure 3.

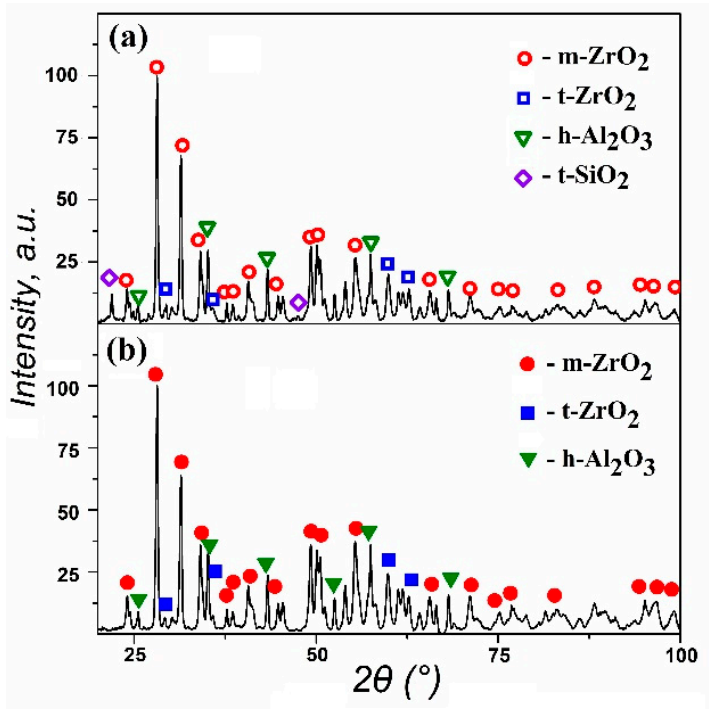

Figure 3. XRD diffractograms for $\mathrm{ZrB}_{2}-\mathrm{MoSi}_{2}$ coating after thermal treatment at $1500{ }^{\circ} \mathrm{C}$ in air for $1 \mathrm{~h}(\mathbf{a})$, and $6 \mathrm{~h}(\mathbf{b})$.

The reactions of the main phases in the composite coatings were shown to have a great effect on the microstructure modification. The reactions can be described as follows:

$$
\begin{gathered}
2 \mathrm{ZrB}_{2}(\mathrm{~s})+5 \mathrm{O}_{2}(\mathrm{~g}) \rightarrow 2 \mathrm{ZrO}_{2}(\mathrm{~s})+2 \mathrm{~B}_{2} \mathrm{O}_{3}(\mathrm{~g}) \\
2 \mathrm{MoSi}_{2}(\mathrm{~s})+7 \mathrm{O}_{2}(\mathrm{~g}) \rightarrow 2 \mathrm{MoO}_{3}(\mathrm{~g}) \rightarrow 4 \mathrm{SiO}_{2}(\mathrm{~s})
\end{gathered}
$$

The XRD patterns of the coating after treatment at $1500{ }^{\circ} \mathrm{C}$ in air for $1 \mathrm{~h}$ are presented in Figure $3 \mathrm{a}$. It can be seen that $\mathrm{m}-\mathrm{ZrO}_{2}, \mathrm{~h}-\left(\alpha-\mathrm{Al}_{2} \mathrm{O}_{3}\right)$, and some $\mathrm{t}-\mathrm{SiO}_{2}$ were detected. The $\mathrm{Y}_{2} \mathrm{O}_{3}$ stabilized cubic phase $\left(\mathrm{c}-\mathrm{ZrO}_{2}\right)$ was found in the coating after treatment at $1500{ }^{\circ} \mathrm{C}$ in air for $1 \mathrm{~h}$.

$\mathrm{Al}_{2} \mathrm{O}_{3}$ is a reaction product of $\mathrm{Al}$ particles with oxygen during heat treatment according to reaction (3):

$$
4 \mathrm{Al}(\mathrm{s})+3 \mathrm{O}_{2}(\mathrm{~g}) \rightarrow 2 \mathrm{Al}_{2} \mathrm{O}_{3}(\mathrm{~s})
$$

Alumina promotes wetting and bonding with carbon/carbon composites as well as exhibiting excellent thermal and chemical stability (melting point $2072^{\circ} \mathrm{C}$ ).

No new phases were formed during heat treatment at $1500^{\circ} \mathrm{C}$ in air for $6 \mathrm{~h}$. According to the results of an X-ray examination obtained after heat treatment at $1500{ }^{\circ} \mathrm{C}$ for $6 \mathrm{~h}$ (Figure $4 \mathrm{~b}$ ), the $\mathrm{t}-\mathrm{SiO}_{2}$ phase was not detected. $\mathrm{SiO}_{2}$ can hardly be detected in XRD, because it covers the surface of grains $\mathrm{ZrO}_{2}$ and $\mathrm{Al}_{2} \mathrm{O}_{3}$, and the growth of grains was observed after heat treatment for $6 \mathrm{~h}$ (Figure 6b).

Figure 4 exhibits the cross-section micrographs of the $\mathrm{ZrB}_{2}-\mathrm{MoSi}_{2}$ coated substrate. In Figure 4, the cross-section of the coated sample (Figure 4a) reveals a defect-free structure showing a sufficiently dense structure containing a small amount of unmelted thick particles (partially melted area). Most of the powder particles melted (fully melted area). It was found that the shape of the fully melted area had as lamellar-like structure (typical for thermally sprayed coatings) and that of the partially melted region was non-uniform, ranging from spherical to lamella. The porosity of the coating was about $1.0 \%$. 

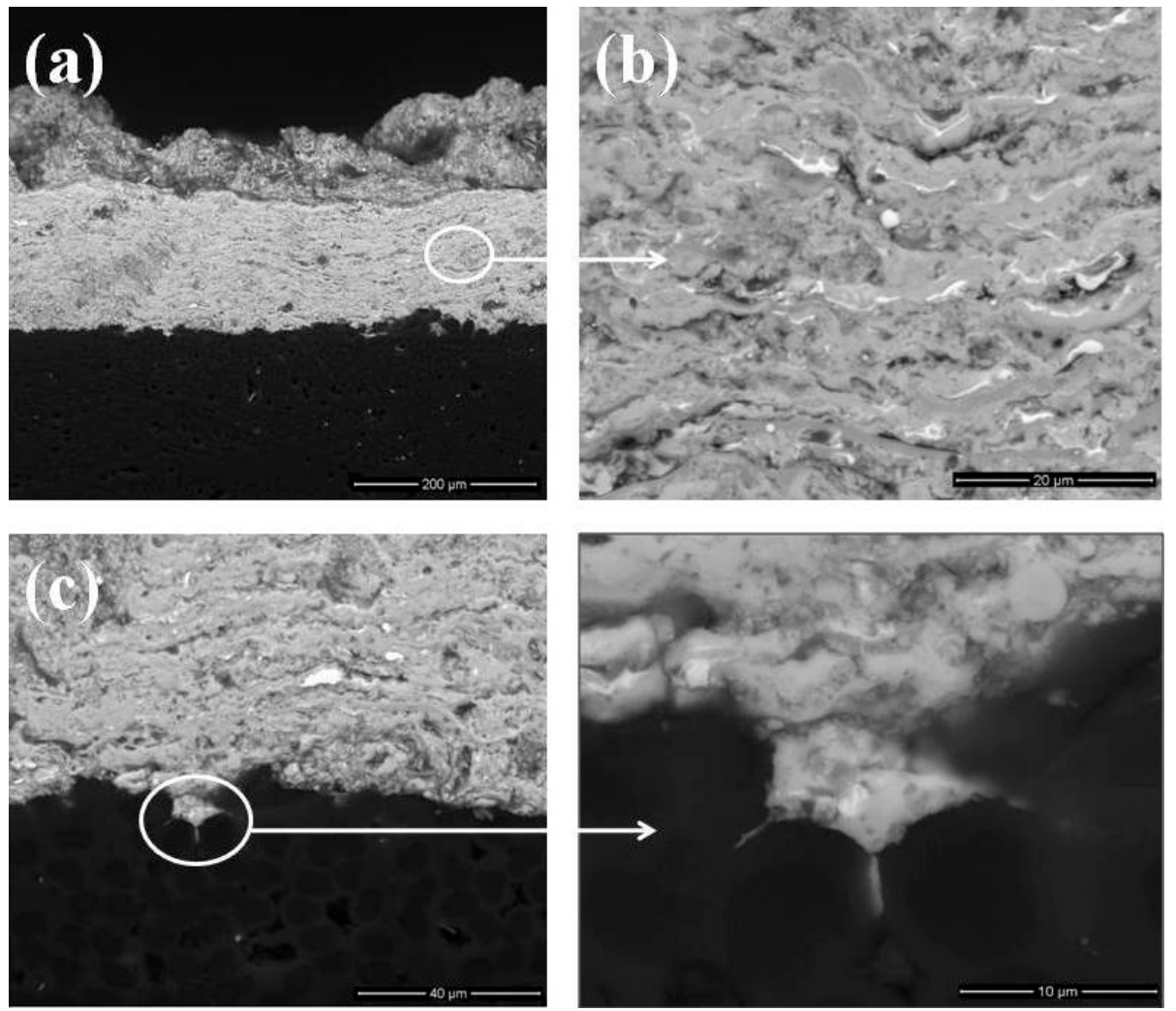

Figure 4. Cross-section SEM micrographs of the $\mathrm{ZrB}_{2}-\mathrm{MoSi}_{2}$ coating (back-scattered electron mode) before treatment (a), lamellar structure $(\mathbf{b})$, and ceramic layer-substrate interface $(\mathbf{c})$.

Figure 4 shows good adhesion between the $\mathrm{ZrB}_{2}-\mathrm{MoSi}_{2}$ coating and the substrate, with no penetrating cracks or voids across the coating. In addition, as shown in Figure 4c, some coating materials penetrated into the substrate during the deposition process, enhancing the adhesion strength between the substrate and coating. The ceramic particle kinetic energy ensured the destruction of the weakened areas on the $\mathrm{C} / \mathrm{C}$ surface and the incorporation of these particles into the surface layer (Figure 4c). Fragile materials on the surface of $\mathrm{C} / \mathrm{C}$ composites (carbon matrix) were destroyed, leading to the formation of voids and cavities. Discrete ceramic particles were broken and fixed in cavities. The following powder particles decelerated on the already fixed particles and formed a ceramic coating with low porosity (Figure 4c).

Figure 5 shows the microstructure of the fracture surface of the $\mathrm{ZrB}_{2}-\mathrm{MoSi}_{2}$ coating before, and after treatment at $1500{ }^{\circ} \mathrm{C}$ in air for 1 and $6 \mathrm{~h}$. The SEM image (Figure 5a) reveals that before heat treatment, the coating was composed of a fully molten area and an insufficiently molten area. These molten phases made un-melted particles stick together. There were no voids in the insufficiently molten area. Very few pores were observed for coating materials. $\mathrm{The}_{\mathrm{SiO}}$ (amorphous) phase was randomly distributed in the coating material (Figure 5a). 

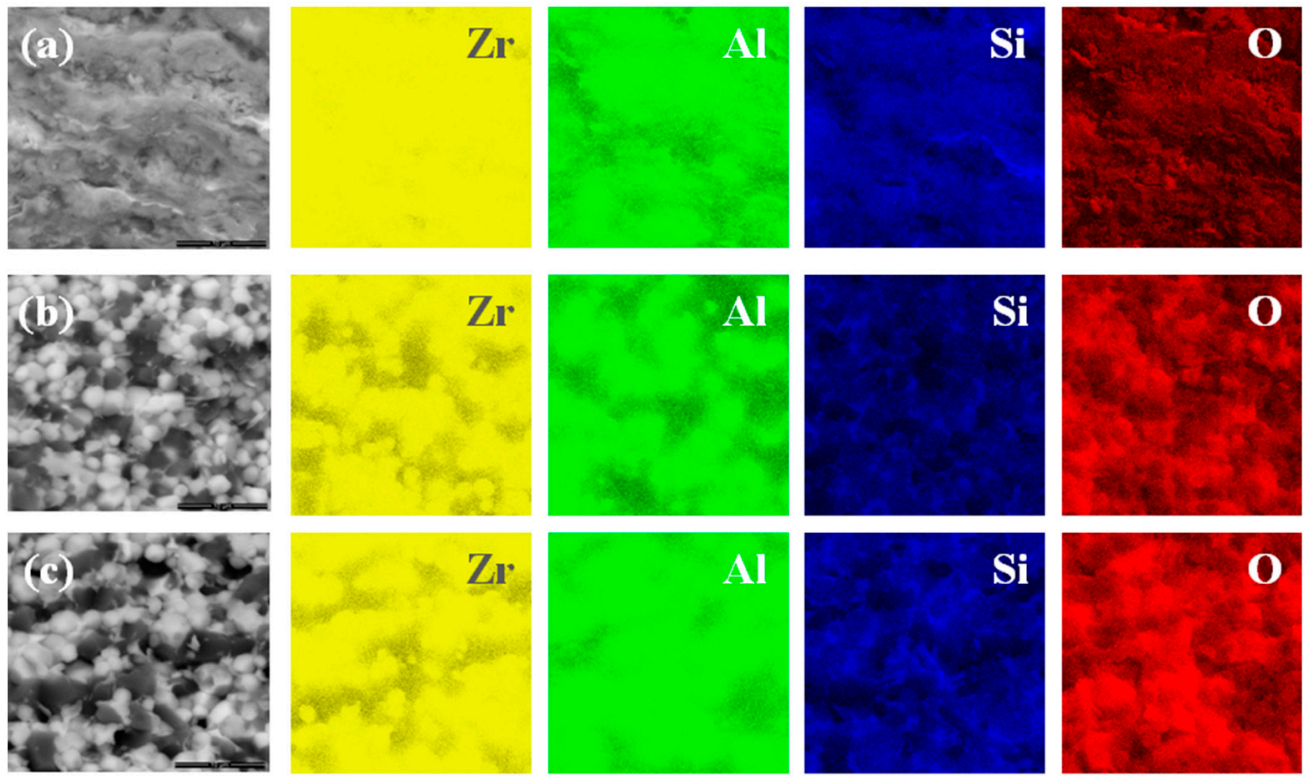

Al
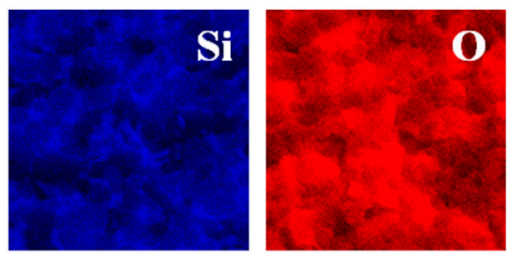

Figure 5. SEM micrographs of fractured surface (back-scattered electron mode) and SEM EDX element distribution maps of the $\mathrm{ZrB}_{2}-\mathrm{MoSi}_{2}$ coating before (a), and after treatment at $1500{ }^{\circ} \mathrm{C}$ in air for $1 \mathrm{~h}(\mathbf{b})$, and $6 \mathrm{~h}(\mathbf{c})$.

The coatings after heat treatment ( 1 and $6 \mathrm{~h}$ ) exhibited structures without cracks, as well as a low porosity. After heat treatment at $1500{ }^{\circ} \mathrm{C}$ in air for $1 \mathrm{~h}$ and $6 \mathrm{~h}$, the coating had porosity values below $1 \%$. This was mainly caused by the fusion of $\mathrm{SiO}_{2}$ at $1500{ }^{\circ} \mathrm{C}$ (Figure $6 \mathrm{c}$ ), which could flow to fill the interlayer pores [27].
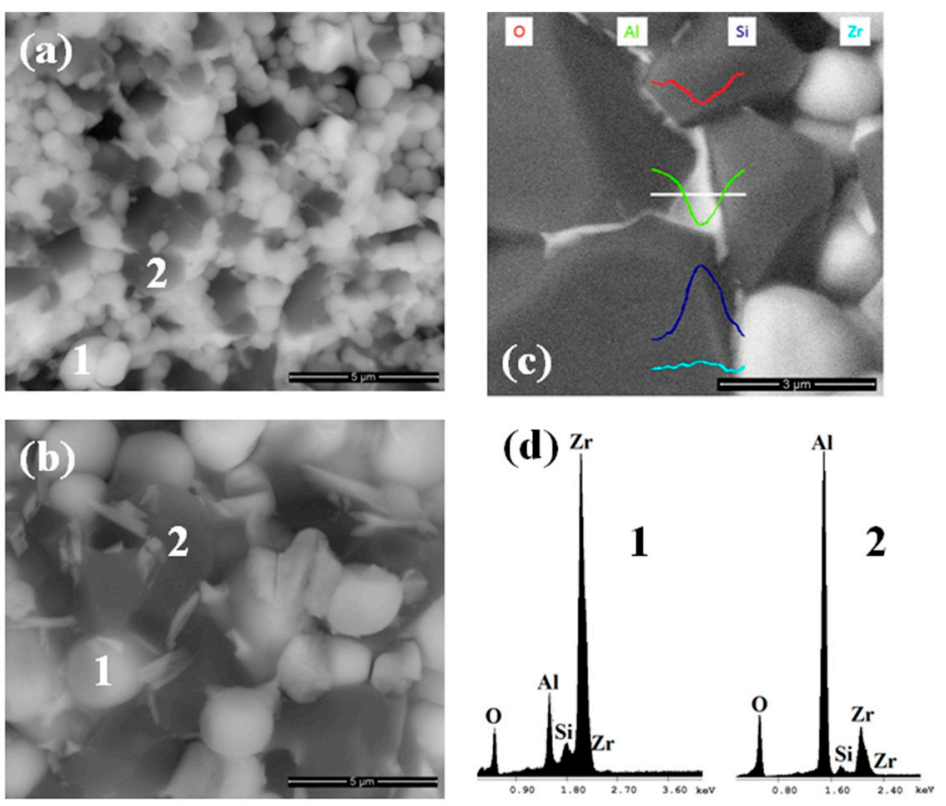

Figure 6. SEM-BSE micrographs of fractured surface of the $\mathrm{ZrB}_{2}-\mathrm{MoSi}_{2}$ coating after treatment at $1500{ }^{\circ} \mathrm{C}$ in air for $1 \mathrm{~h} \mathrm{(a)}$ and $6 \mathrm{~h}(\mathbf{b})$, SEM-EDX line scan analysis (c), EDX spectrum (d).

Changes in the coating's microstructure were observed after heat treatment (Figures 5 and 6). The EDX results (Figure 6) indicated that the white phase (globular grains) marked as 1 was composed of $\mathrm{ZrO}_{2}$, and the dark gray phase marked as 2 was composed of $\mathrm{Al}_{2} \mathrm{O}_{3}$. The $\mathrm{Al}_{2} \mathrm{O}_{3}$ phase was characterized by low dihedral angles and an irregular shape. The light gray phase was $\mathrm{SiO}_{2}$ (Figure 6c). 
The three phases were distributed evenly, no aggregation was observed, and there were very few pores. Glassy $\mathrm{SiO}_{2}$ possesses a low oxygen diffusion coefficient at $1473 \mathrm{~K}$ and can reduce the velocity of oxygen through the coating [11-15]. The spray torch has a very high temperature and can melt particles These particles were impacted on the cold substrate to form a coat in less than a second. This ultrafast speed and great temperature variation are essential conditions for glass formation. The mean grain size after heat treatment for $1 \mathrm{~h}$ was in the range of $0.82-1.85 \mu \mathrm{m}$.

The growth of grains was observed after heat treatment for $6 \mathrm{~h}$ (Figures 5 and 6). At high magnification (Figure $6 \mathrm{~b}$ ), it was found that the grain size was about 2.11-2.82 $\mu \mathrm{m}$ and a thin continuous silica-rich film covered their surfaces, as confirmed by EDS (Figure 6c). Silica could have played a role during heat treatment by acting as grain lubricant for particle rearrangement.

\section{Conclusions}

A multi-chamber detonation accelerator (MCDS) was applied for deposition of the $\mathrm{ZrB}_{2}-\mathrm{MoSi}_{2}$ coating on carbon/carbon composites. MCDS provided the conditions for the formation of dense (porosity $\sim 1 \%$ ) and uniform coating layers. The coating with thickness of $\sim 150 \mu \mathrm{m}$ presented a compact structure, and no obvious holes and cracks could be found. The penetrative cracks and pores in the coating were not found before and after oxidation at $1500{ }^{\circ} \mathrm{C}$ in air for 1 and $6 \mathrm{~h}$. The resistance to oxidation was ascribed to the positive effect of $\mathrm{Y}_{2} \mathrm{O}_{3}$, which stabilized $\mathrm{ZrO}_{2}$, and the uniform distribution of $\mathrm{SiO}_{2}$ particles, which was able to restrain the extension of the cracks and generate the shrinkage of $\mathrm{ZrO}_{2}$ during heat treatment. In the framework of further research, the production and study of the high-temperature oxidation of carbon/carbon composites with $\mathrm{ZrB}_{2}-\mathrm{xMoSi}_{2}(\mathrm{x}=20$, 30,40 mol. \%) coatings modified by $\mathrm{Y}_{2} \mathrm{O}_{3}$ and $\mathrm{Al}$ will be carried out. The results will open up new prospects for the further elaboration of new technologies for making a protective coating that can enhance the properties of carbon/carbon composites in an oxidizing atmosphere at high temperatures.

Author Contributions: Conceptualization, M.K.; Data curation, V.N. and Y.T.; Formal analysis, M.K., V.S., Y.T. and O.K.; Investigation, I.G., O.V. and I.P.; Methodology, M.Y., V.S. and O.K.; Writing - original draft, M.K. All authors read and approved the manuscript.

Funding: This research was funded by the Russian Science Foundation, under grant No 19-19-00274. The studies were carried out on the equipment of the Centre for High Technologies of BSTU and the Joint Research Center of Belgorod State National Research University «Technology and Materials».

Acknowledgments: The authors would like to thank Yuri Tyurin (E.O. Paton Electric Welding Institute, NASU) for his helpful advice on various technical issues examined in this paper, and Oleg Kolisnichenko (E.O. Paton Electric Welding Institute, NASU) for his advice and comments.

Conflicts of Interest: The authors declare no conflict of interest.

\section{References}

1. Devi, G.; Rao, K. Carbon-carbon Composites-An Overview. Def. Sci. J. 1993, 43, 369-383. [CrossRef]

2. Sheehan, J.E.; Buesking, K.W.; Sullivan, B.J. Carbon-Carbon Composites. Annu. Rev. Mater. Sci. 2003, 24, 19-44. [CrossRef]

3. Jacobson, N.S.; Curry, D.M. Oxidation Microstructure Studies of Reinforced Carbon/Carbon. Carbon 2006, 44, 1142-1150. [CrossRef]

4. Lalit, M.M. High Performance Carbon-carbon Composites. Sadhana 2003, 28, 349-358. [CrossRef]

5. Windhorst, T.; Blount, G. Carbon-Carbon Composites: A Summary of Recent Developments and Applications. Mater. Des. 1997, 18, 11-15. [CrossRef]

6. Smeacetto, F.; Ferraris, M.; Salvo, M. Multilayer Coating with Self-sealing Properties for Carbon-carbon Composites. Carbon 2003, 41, 2105-2111. [CrossRef]

7. Park, S.-J.; Seo, M.-K. The Effect of $\mathrm{MoSi}_{2}$ on the Oxidation Behavior of Carbon/Carbon Composites. Carbon 2001, 39, 1229-1235. [CrossRef]

8. Sciti, D.; Brach, M.; Bellosi, A. Oxidation Behavior of a Pressureless Sintered $\mathrm{ZrB}_{2}-\mathrm{MoSi}_{2}$ Ceramic Composite. Mater. Res. Soc. 2005, 20, 922-930. [CrossRef] 
9. Mao, J.Y.; Liu, M.; Mao, J. Oxidation-resistance of $\mathrm{ZrB}_{2}-\mathrm{MoSi}_{2}$ Composite Coatings Prepared by Atmospheric Plasma Spraying. J. Inorg. Mater. 2015, 39, 282-286.

10. Liu, X.; Han, W.; Wen, K.; Deng, C.; Liu, M.; Zhou, K. Bimodal Microstructure ZrB $2-\mathrm{MoSi}_{2}$ Coating Prepared by Atmospheric Plasma Spraying for Carbon/carbon Composites Against Long-term Ablation. Ceram. Int. 2017, 43, 16659-16667. [CrossRef]

11. Zhang, W.Z.; Yi, Z.; Lemuel, G.; Xiang, X.; Bai-yun, H. Preparation and Oxidation Property of $\mathrm{ZrB}_{2}-\mathrm{MoSi}_{2} / \mathrm{SiC}$ Coating on Carbon/carbon Composites. Trans. Nonferrous Met. Soc. China 2011, 21, 1538-1544. [CrossRef]

12. Yang, X.; Wei, L.; Song, W.; Bi-Feng, Z.; Zhao-Hui, C. ZrB $2 /$ SiC as a Protective Coating for C/SiC Composites: Effect of High Temperature Oxidation on Mechanical Properties and Anti-ablation Property. Compos. Part B-Eng. 2013, 45, 1391-1396. [CrossRef]

13. Yang, X.; Feng, C.; Qing, W. $\mathrm{ZrB}_{2}-\mathrm{SiC}$ as a Protective Coating for C/SiC Composites: Effect of High Temperature Oxidation on Thermal Shock Property and Protection Mechanism. J. Asian Ceram. 2016, 4, 159-163. [CrossRef]

14. Zhang, Y.; Hu, Z.; Li, H.; Ren, J. Ablation Resistance of $\mathrm{ZrB}_{2}-\mathrm{SiC}$ Coating Prepared by Supersonic Atmosphere Plasma Spraying for SiC-coated Carbon/carbon Composites. Ceram. Int. 2014, 40, 14749-14755. [CrossRef]

15. Li, C.; Li, G.; Ouyang, H.; Lu, J. ZrB 2 Particles Reinforced Glass Coating for Oxidation Protection of Carbon/carbon Composites. J. Adv. Ceram. 2019, 8, 102-111. [CrossRef]

16. Xu, B.; He, R.; Hong, C.; Ma, Y.; Wen, W.; Li, H.; Cheng, T.; Fang, D.; Yang, Y. Ablation Behavior and Mechanism of Double-layer $\mathrm{ZrB}_{2}$-Based Ceramic Coating for Lightweight Carbon-bonded Carbon fiber Composites Under Oxyacetylene Flame at Elevate Temperature. J. Alloys Compd. 2017, 702, 551-560. [CrossRef]

17. Niu, Y.; Wang, H.; Li, H.; Zhenga, X.; Ding, C. Dense $\mathrm{ZrB}_{2}-\mathrm{MoSi}_{2}$ Composite Coating Fabricated by Low Pressure Plasma Spray (LPPS). Ceram. Int. 2013, 39, 9773-9777. [CrossRef]

18. Pierre, L.F.; Joachim, V.R.; Maher, I.B. Thermal Spray Fundamentals: From Powder to Part; Springer: Berlin, Germany; New York Inc.: New York, NY, USA, 2013; pp. 943-944.

19. Vasilik, N.; Tyurin, Y.; Kolisnichenko, O. Method for Gas-Dynamic Detonating Speedup of Powders and Device for its Implementation. RU Patent 2,506,341, 11 July 2012.

20. Kovaleva, M.; Tyurin, Y.; Vasilik, N.; Kolisnichenko, O.; Prozorova, M.; Arseenko, M.; Danshina, E. Deposition and Characterization of $\mathrm{Al}_{2} \mathrm{O}_{3}$ Coatings by Multi-chamber Gas-dynamic Accelerator. Surf. Coat. Technol. 2013, 232, 719-725. [CrossRef]

21. Kovaleva, M.; Prozorova, M.; Arseenko, M.; Tyurin, Y.; Kolisnichenko, O.; Yapryntsev, M.; Novikov, V.; Vagina, O.; Sirota, V. Zircon-based Ceramic Coatings Formed by a New Multi-chamber Gas-dynamic Accelerator. Coatings 2017, 7, 142. [CrossRef]

22. Elshalakany, A.B.; Osman, T.A.; Hoziefad, W.; Escudera, A.V.; Amigóa, V. Comparative Study Between High-velocity Oxygen Fuel and Flame Spraying Using MCrAlY Coats on a 304 Stainless Steel Substrate. J. Mater. Res. Technol. 2019, 8, 4253-4263. [CrossRef]

23. da Cunha, C.A.; Nelson, B.L.; Martinelli, J.R.; da Almeida Bressiani, A.H.; Padial, A.G.F.; Ramanathan, L.V. Microstructure and Mechanical Properties of Thermal Sprayed Nanostructured Cr3C2-Ni20Cr Coatings. Mater. Res. 2008, 11, 137-143. [CrossRef]

24. Li, C.J.; Ohmori, A. Relationships Between the Microstructure and Properties of Thermally Sprayed Deposits. J. Therm. Spray Technol. 2002, 11, 365-374. [CrossRef]

25. Lu, W.; Qian-gang, F.; Ning-kun, L.; Sun, J. Improvement of the Adhesion Strength of $\mathrm{MoSi}_{2}-\mathrm{ZrB}_{2}$ Coating by Optimizing Particle Spraying and Subsequent Heat Treatment. J. Therm. Spray Technol. 2016, 25, 1280-1288. [CrossRef]

26. Niu, Y.; Wang, Z.; Zhao, J.; Zheng, X.; Zeng, Y.; Ding, C. Comparison of ZrB $2-\mathrm{MoSi}_{2}$ Composite Coatings Fabricated by Atmospheric and Vacuum Plasma Spray Processes. J. Therm. Spray Technol. 2017, 26, 100-107. [CrossRef]

27. Fu, Q.G.; Li, H.J.; Shi, X.H.; Li, K.Z.; Sun, G.D. Silicon Carbide Coating to Protect Carbon/Carbon Composites Against Oxidation. Script. Mater. 2005, 52, 923-927. [CrossRef]

(C) 2019 by the authors. Licensee MDPI, Basel, Switzerland. This article is an open access article distributed under the terms and conditions of the Creative Commons Attribution (CC BY) license (http://creativecommons.org/licenses/by/4.0/). 